\title{
PENGARUH KEPUASAN DAN FASILITAS TERHADAP LOYALITAS KONSUMEN DI HOTEL PLATINUM RANTAUPRAPAT KABUPATEN LABUHANBATU
}

\author{
Sigit Riadi ${ }^{1}$, Junita Lubis ${ }^{2}$ \\ ${ }^{1}$ Alumni Sarjana Ekonomi STIE Labuhanbatu \\ ${ }^{2}$ Dosen STIE Labuhanbatu
}

\begin{abstract}
ABSTRAK
.Penelitian ini bertujuan untuk mengetahui pengaruh Kepuasan dan Fasilitas terhadap Loyalitas Konsumen di Hotel Platinum Rantauprapat Kabupaten Labuhanbatu. Jenis penelitian ini adalah penelitian asosiatif. Teknik pengambilan sampel menggunakan metode Insidental Sampling. Jenis data yang digunakan adalah data primer dan data sekunder. Teknik analisis data yang digunakan dalam penelitian ini adalah analisis deskriptif, analisis regresi linear berganda, pengujian hipotesis dengan menggunakan uji signifikan simultan (uji F), pengujian signifikan parsial (uji t), dan pengujian koefisien determinasi $\left(\mathrm{R}^{2}\right)$. Hasil penelitian ini menunjukkkan bahwa secara bersama-sama adanya pengaruh positif dan signifikan antara variable Kepuasan dan Fasilitas terhadap Loyalitas Konsumen di Hotel Platinum Rantauprapat Kabupaten Labuhanbatu (uji F). Pada pengujian secara parsial (uji t) diketahui bahwa variabel Kepuasan berpengaruh positif dan signifkan terhadap Loyalitas Konsumen di Hotel Platinum Rantauprapat Kabupaten Labuhanbatu. Variabel Fasilitas yang berpengaruh positif dan signifikan terhadap Loyalitas Konsumen di Hotel Platinum Rantauprapat Kabupaten Labuhanbatu. Melalui pengujian koefisien determinasi ( $R$ Square) sebesar 0,643 berarti 64,3\% faktor-faktor Loyalitas Konsumen Konsumen dapat dijelaskan oleh Kepuasan dan Fasilitas. Sedangkan sisanya 35,7\% dapat dijelaskan oleh faktor-faktor lain yang tidak diteliti.
\end{abstract}

\section{Kata Kunci: Kepuasan, Fasilitas dan Loyalitas Konsumen.}

\section{Pendahuluan}

Latar Belakang Masalah

Perkembangan persaingan bisnis di Indonesia merupakan salah satu fenomena saat ini, terlebih dengan adanya globalisasi yang mendorong informasi lebih cepat tersebar. Hal ini dapat terjadi karena adanya persaingan dalam dunia usaha, baik perusahaan manufaktur, dagang maupun jasa. Untuk menghadapi persaingan, setiap perusahaan dapat melakukan berbagai strategi kepada konsumen dengan mengetahui keinginan dan kebutuhannya sehingga timbul loyalitas atas keinginan dan kebutuhan tersebut.
Bagi perusahaan yang bergerak di bidang jasa, dalam menjaga dan memperhatikan kesetiaan pelanggan merupakan peluang besar guna memperoleh keuntungan maksimal dari pelanggan tersebut. Loyalitas pelanggan merupakan suatu bentuk hubungan yang kuat antara pelanggan dengan perusahaan. Loyalitas dipandang sebagai perilaku yang didasarkan pada kepuasan konsumen.

Loyalitas pelanggan akan membuat perusahaan memiliki sumber pendapatan pasti (dari pelanggan loyal) sehingga akan membuat perusahaan tersebut mampu bersaing dalam jangka waktu panjang. 
Seorang pelanggan menjadi setia biasanya bukan dikarenakan salah satu aspek dalam perusahaan saja, tetapi biasanya pelanggan menjadi setia karena sesuatu hal yang ditawarkan seperti produk, pelayanan dan harga.

Ada tiga hal kriteria untuk mengetahui pelanggan setia antara lain :

1. Keinginan untuk membeli produk dan jasa dari perusahaan tanpa membandingkan produk dan jasa yang ditawarkan dengan pesaing.

2. Merekomendasikan perusahaan, produk, dan pelayanan perusahaan dari mulut ke mulut kepada orang lain.

3. Tindakan proaktif untuk memberikan saran produk atau jasa kepada perusahaan.

Dari ketiga kriteria tersebut menjelaskan bahwa loyalitas pelanggan terbentuk melalui sebuah proses dan membutuhkan waktu, karena dalam proses terciptanya loyalitas pelanggan, pelanggan sebelumnya harus merasakan manfaat produk dan jasa yang ditawarkan perusahaan, artinya pelanggan merasakan kepuasan atas manfaat produk dan jasa perusahaan.

Untuk menciptakan kepuasan pelanggan, maka perusahaan harus menciptakan dan mengelola suatu sistem yang baik untuk mempertahankan pelanggannya. Kepuasan merupakan bentuk perasaan senang /kecewa seseorang yang berasal dari adanya perbandingan antara kesannya terhadap kinerja dan harapan-harapannya. Oleh karena itu, keterkaitan kepuasan pelanggan menjadi pendorong utama terciptanya kesetiaan pelanggan yang dipengaruhi berbagai aspek penting yang terdapat dalam perusahaan.

Adanya fasilitas dapat mempermudah upaya menciptakan kepuasan konsumen yang diberikan perusahaan. Fasilitas yang diberikan menimbulkan rasa menyenangkan yang diberikan kepada konsumen disertai kemudahan untuk memenuhi kebutuhan mereka. Fasilitas ini sifatnya lebih berorientasi kepada perasan konsumen terhadap fasilitas yang diberikan; Setelah fasilitas diberikan, konsumen mungkin merasakan mendapatkan fasilitas yang sesuai atau tidak sesuai dengan yang diharapkan. Fasilitas juga sulit untuk di standarisasi karena fasilitas bisa dipandang berbeda-beda : oleh orang yang berbeda dalam suatu kelompok budaya yang sama, oleh orang yang sama pada waktu dan suasana hati yang berbeda atau oleh orang dengan latar belakang, sosial budaya fasilitas.

Dari survey yang dilakukan penulis, fenomena yang terjadi mengenai fasilitas di Hotel Platinum Rantauprapat Kabupaten Labuhanbatu yaitu beberapa konsumen kurang puas terhadap fasilitas yang ada pada hotel tersebut seperti adanya kerusakan pada saluran listrik, pengaturan udara (AC) set televisi dan perabot lainnya. Keluhan-keluhan tamu lainnya juga menyebabkan loyalitas konsumen berkunjung ke hotel platinum rantauprapat kabupaten labuhanbatu juga berkurang seperti : Lounge ditutup lebih awal dari waktu yang ditentukan dan kolam renang ditutup secara mendadak.

Hal ini juga berhubungan dengan kepuasan yang dirasakan oleh konsumen antara lain : Tamu menunggu pesan room service yang terlalu lama, kamar tamu masih tampak kotor, wake-up call terlambat dan makanan serta minumn yang kurang bermutu. Hotel yang tidak dikelola secara professional dan efisien akan ditemui banyak masalah atas tamutamunya. Akan tetapi pihak hotel harus mengusahakan penekanan keluhan itu seminiml mungkin. Ini dilakukan agar 
para tamu merasa puas dengan service yang diharapkan konsumen.

Berdasarkan uraian dari permasalahan yang dikemukakan, maka judul penelitian ini mengenai "Pengaruh Kepuasan Dan Fasilitas Terhadap Loyalitas Konsumen Di Hotel Platinum Rantauprapat Kabupaten Labuhanbatu ".

\section{Batasan Dan Perumusan Masalah}

Batasan Masalah

Batasan masalah dalam penelitian ini adalah membahas permasalahan yang berhubungan dengan Kepuasan, Fasilitas Dan Loyalitas Konsumen di Hotel Platinum Kabupaten Labuhanbatu

Perumusan Masalah

Berdasarkan latar belakang masalah yang telah diuraikan, maka Perumusan masalah dalam penelitian ini sebagai berikut:

1. Apakah Kepuasan berpengaruh positif dan signifikan terhadap Loyalitas Konsumen Di Hotel Platinum Rantauprapat Kabupaten Labuhanbatu?

2. Apakah Fasilitas berpengaruh positif dan signifikan terhadap Loyalitas Konsumen Di Hotel Platinum Rantauprapat Kabupaten Labuhanbatu?

3. Apakah Kepuasan, dan Fasilitas secara bersama-sama berpengaruh positif dan signifikan terhadap Loyalitas Konsumen Di Hotel Platinum Rantauprapat Kabupaten Labuhanbatu?

\section{Tujuan Penelitian}

Tujuan yang ingin dicapai dalam penelitian ini adalah sebagai berikut:

1. Untuk membuktikan apakah Kepuasan berpengaruh positif dan signifikan terhadap Loyalitas Konsumen Di Hotel
Platinum Rantauprapat Kabupaten Labuhanbatu

2. Untuk membuktikan apakah Fasilitas berpengaruh positif dan signifikan terhadap Loyalitas Konsumen Di Hotel Platinum Rantauprapat Kabupaten Labuhanbatu.

3. Untuk membuktikan apakah Keputusan dan Fasilitas secara bersama-sama berpengaruh positif dan signifikan terhadap Loyalitas Konsumen Di Hotel Platinum Rantauprapat Kabupaten Labuhanbatu.

\section{Manfaat Penelitian}

Hasil dari penelitian ini diharapkan dapat memberikan manfaat bagi berbagai pihak yang berkepentingan, antara lain:

1. Bagi Hotel Platinum Rantauprapat Kabupaten Labuhanbatu., penelitian ini diharapkan dapat menjadi motivasi dan masukan bagi perusahaan untuk mengetahui berapa besar pengaruh Kepuasan Dan Fasilitas Terhadap Loyalitas Konsumen Di Hotel Platinum Rantauprapat Kabupaten Labuhanbatu

2. Bagi Penulis, penelitian ini diharapkan dapat memperluas pengetahuan penulis tentang pemasaran, khususnya mengenai pengaruh Kepuasan dan Fasilitas terhadap Loyalitas Konsumen Di Hotel Platinum Rantauprapat Kabupaten Labuhanbatu

3. Bagi Peneliti Lain, sebagai bahan referensi dan wacana yang nantinya dapat memberikan perbandingan dalam melakukan penelitian lebih lanjut di masa yang akan datang. 


\section{Metode Penelitian}

Lokasi Dan Waktu Penelitian

1. Lokasi Penelitian

Lokasi penelitian dilakukan di Hotel

Platinum Rantauprapat Kabupaten

Labuhanbatu.yang beralamat di J1 SM

Raja No. 28-30, Rantauprapat

2. Waktu Penelitian

Waktu Penelitian ini dimulai bulan

Desember 2015 sampai bulan April 2016.

\section{Populasi dan Sampel Penelitian Populasi}

Populasi adalah keseluruhan dari sekumpulan elemen atau objek dan subjek yang memiliki sejumlah karakteristik umum yang diminati oleh peneliti untuk dipelajari, diteliti dan kemudian ditarik kesimpulan (Sugiyono, 2011). Populasi yang diambil dalam penelitian ini adalah pengunjung Hotel Platinum Rantauprapat Kabupaten Labuhanbatu.

\section{Sampel}

Sampel adalah bagian dari jumlah dan karakteristik yang dimiliki oleh populasi tersebut. Untuk itu sampel yang diambil dari populasi harus betul-betul representative (mewakili). Metode pengambilan sampel menggunakan metode Nonprobability Sampling dengan menggunakan teknik Sampling Insidental. Sugiyono (2011), Sampling Insidental adalah teknik penentuan sampel berdasarkan kebetulan, yaitu siapa saja yang secara kebetulan/incidental bertemu dengan peneliti dapat digunakan sebagai sampel, bila dipandang orang yang kebetulan ditemui cocok sebagai sumber data.

Untuk menentukan jumlah sampel digunakan rumus Supramono dan Haryanto (2006). Alaternatif formula yang digunakan untuk menentukan sampel pada populasi yang sulit diketahui adalah sebagai berikut:

$$
\mathrm{n}=\frac{(\mathrm{Z} \alpha) 2(\mathrm{p})(\mathrm{q})}{(\mathrm{d}) 2}
$$

Keterangan:

$\mathrm{N}=$ Jumlah sampel

$\mathrm{Z} \alpha=$ Nilai standar normal yang besarnya t ergantung $\alpha$

Bila $\alpha=0,05 Z=1,96$

Bila $\alpha=0,01 \mathrm{Z}=1,67$

$\mathrm{p}=$ Estimator proporsi populasi yang sesuai kriteria sampel

$\mathrm{q}=$ Proporsi populasi yang tidak sesuai kriteria sampel (1-p)

$\mathrm{d}=$ Penyimpangan yang ditolerir $10 \%$ Berdasarkan pra survey yang dilakukan oleh penulis secara acak pada 30 orang pengunjung Hotel Platinum Rantauprapat Kabupaten Labuhanbatu pada bulan Maret 2015 ditemukan 25 orang yang menginap $(75 \%) \mathrm{p}=0,75$ dan 5 orang lainnya $(25 \%) \mathrm{q}=0,25$ tidak jadi menginap. Dengan menggunakan rumus tersebut maka dapat menghasilkan jumlah sampel sebagai berikut:

$$
\begin{aligned}
\mathrm{n} & =\frac{(\mathrm{Z} \alpha) 2(\mathrm{p})(\mathrm{q})}{(\mathrm{d}) 2} \\
\mathrm{n} & =\frac{(1,67) 2(0,75)(0,25)}{(0,1) 2} \\
& =52,29=52 \text { orang }
\end{aligned}
$$

\section{Kerangka Konseptual}

Kerangka konseptual penelitian adalah suatu hubungan atau kaitan antara konsep satu terhadap konsep yang lainya dari masalah yang ingin diteliti. Kerangka ini didapatkan dari konsep ilmu atau teori yang dipakai sebagai landasan penelitian yang didapatkan pada tinjauan pustaka atau merupakan ringkasan dari tinjauan pustaka yang dihubungkan dengan garis sesuai variabel yang diteliti.

Menurut Kotler dan Keller (2009) Kepuasan adalah tingkat perasaan seseorang setelah membandingkan kinerja 
(atau hasil) yang ia persepsikan dibandingkan dengan harapannya. Seorang pelanggan jika merasa puas dengan nilai yang diberikan oleh produk atau jasa maka sangat besar kemungkinannya untuk menjadi pelanggan dalam waktu yang lama.

Tjiptono

(2008:59)

mengemukakan fasilitas adalah sumber daya fisik yang harus ada sebelum suatu jasa ditawarkan kepada konsumen. Pada dasarnya fasilitas merupakan faktor yang menentukan untuk menginap disuatu hotel tertentu. Pengunjung akan merasa senang apabila dalam suatu hotel fasilitas tersebut tersedia. Setelah fasilitas diberikan, pengunjung akan merasakan mendapatkan fasilitas yang sesuai dengan yang diharapkan. Adanya fasilitas yang terpenuhi untuk memberikan kemudahan kepada penggunanya, sehingga kebutuhan-kebutuhan dari pengguna fasilitas tersebut dapat terpenuhi.

Griffin (2007) mengemukakan konsep loyalitas mengarah kepada prilaku (behaviour) dibandingkan dengan sikap (attitude) dan seorang pelanggan yang loyal akan memperlihatkan prilaku pembelian yang didefinisikan sebagai pembeli yang teratur dan diperlihatkan sepanjang waktu oleh beberapa unit pembuatan keputusan". Konsumen yang loyal merupakan aset bagi perusahaan, dan untuk mengetahui pelanggan yang loyal perusahaan harus mampu menawarkan produk atau jasa yang dapat memenuhi harapan pelanggan serta dapat memuaskan pelanggannya

Berdasarkan tinjauan pustaka dan penelitian terdahulu maka dapat disusun kerangka konseptual penelitian sebagaimana dapat dilihat pada gambar sebagai berikut :

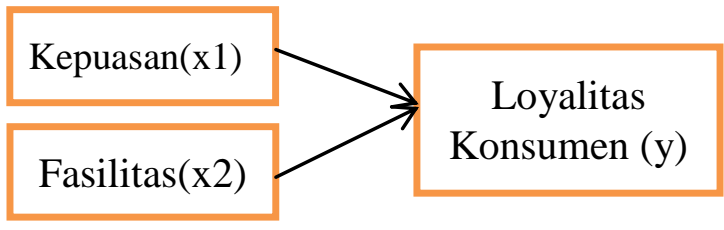

Sumber: Kotler dan Keller (2009), Tjiptono (2008) dan Griffin (2007)

Gambar 2.2

Kerangka Konseptual

\section{Hasil Penelitian \\ Profil Hotel Platinum Rantauprapat}

Berdasarkan Keputusan Menteri Parpostel no Km 94/HK103/MPPT 1987, pengertian hotel adalah Salah satu jenis akomodasi yang mempergunakan sebagian atau keseluruhan bagian untuk jasa pelayanan penginapan, penyedia makanan dan minuman serta jasa lainnya bagi masyarakat umum yang dikelola secara komersil. Usaha pengelolaan hotel perhotelan merupakan sebuha usaha yang mencari keuntungan dengan menjual tiga produk utama yaitu: penyewaan kamar, penjualan makanan dan minuman serta penyewaan fasilitas. Oleh karena itu bisni perhotelan harus ditunjang dengan struktur organisasi yang sangat baik.

Hotel Platinum Rantauprapat yang dibangun sejak tahun 2012 dikelola secara komersil dengan memberikan fasilitas penginapan untuk masyarakat umum dengan fasilitas sebagai berikut

1. Jasa penginapan

2. Pelayanan makanan dan minuman

3. Pelayanan barang bawaan

4. Pencucian pakaian

5. Penggunaan fasilitas perabot dan hiasan-hiasan yang ada di dalamnya.

Fasilitas-fasilitas yang ada di Hotel Platinum Rantauprapat meliputi Sarana yang disediakan untuk tamu yang dapat digunakan untuk santai, fitur Kamar 
seperti kamar yang luas dengan desain kontemporer lengkap, konfigurasi kamar double maupun single, AC yang dapat dikontrol secara individual, kunci kamar elektronik, kamar mandi dan mesin pengering rambut, fasilitas mesin untuk membuat kopi dan the, TV dengan sambungan satelit Internasional, WIFI Internet access, CD player dan sandal untuk di kamar.

Untuk Room Type terdiri dari Standard Room (Tersedia Single Bed ataupun Double Bed. AC + TV + Wardrobe + Hot \& Cold Water), Deluxe Room (AC + TV + Wardrobe + Hot \& Cold Water), Family Suite (AC + TV + Wardrobe + Hot $\&$ Cold Water +1 Single Bed +1 Double Bed), President Suite $(\mathrm{AC}+\mathrm{TV}+$ Refrigerator + Guest Room + Wardrobe + Hot \& Cold Water)

Berdasarkan lokasi dimana hotel ini dibangun, Hotel Platinum Rantauprapat juga termasuk kedalam jenis City Hotel. Hotel yang berlokasi di perkotaan, diperuntukkan bagi masyarakat yang bermaksud untuk tinggal sementara (dalam jangka waktu pendek). City Hotel disebut juga sebagai transit hotel karena biasanya dihuni oleh para pelaku bisnis yang memanfaatkan fasilitas dan pelayanan bisnis yang disediakan oleh hotel tersebut.

\section{Visi dan Misi Hotel Platinum} Rantauprapat Visi Hotel Platinum Rantauprapat

"Kami selalu memprioritaskan kenyamanan dan kepuasan tamu kami selama menginap".

\section{Misi Hotel Platinum Rantauprapat}

"Kami bertujuan untuk memberikan pelayanan hotel yang berkualitas dengan pelayanan yang ramah dengan desain yang unik yang akan membuat orang senang dan tersenyum dan kepuasan kepada seluruh kalangan."

\section{Uraian Fungsi Dan Tugas di Hotel Platinum Rantauprapat}

1. General Manager

General Manager adalah puncak pimpinan dari sebuah struktur organisasi hotel. Ia bertanggung jawab atas keseluruhan penyelenggaraan hotel dan kinerja seluruh karyawannya.

2. Assistant General Manager atau

Executive Assistan Manager.

Yang ke dua dari struktur organisasi hotel adalah : Assistant General Manager atau Executive Assistan Manager adalah wakil General Manager. Jabatan ini pada umumnya ada di hotel-hotel besar di mana General Manager perlu dibantu dan didukung oleh Assistan General Manager. Penanganan tugas-tugas manajemen yang telah dirumuskan dan diarahkan oleh General Manager dilaksanakan dan dikomunikasikan kepada Assistant General Manager. Selanjutnya diteruskan ke Departmen Head.

3. Controller

Controller adalah akuntan internal hotel. Controller bertanggung jawab atas efektivitas pengelolaan administrasi dan penyajian data keuangan yang disusun setiap hari. Ia akan dimintai pendapat dan pandangannya dalam hal keuangan hotel.

4. Plant Engineer

Plant Engineer adalah pejabat yang bertanggung jawab atas pemeliharaan, pengelolaan, dan perbaikan seluruh aset yang meliputi: gedung hotel, perlengkapan mekanik dan elektronik, dan energi hotel. Pengelolaan listrik, gas, dan air adalah tanggung jawab plant engineer. 
5. Executive Housekeeper

Executive Housekeeper adalah pemimpin departemen yang memiliki kemampuan merencanakan, mengorganisasi, dan mengevaluasi pekerjaan dibidang housekeeping. Ia bertanggung jawab atas kebersihan kamar-kamar tamu dan area umum yang dimiliki hotel.

6. Human Resources Development Manager

HRD Manager adalah pejabat yang bertugas mengelola sumber daya manusia untuk keberhasilan hotel. HRD Manager harus menguasai hukum dan perundang-undangan yang berkaitan dengan ketenagakerjaan, baik lokal, nasional, maupun internasional. Ia bertugas menerima dan mengangkat pegawai baru, menyelenggarakan semua administrasi kepegawaian dan kegiatan karyawan, serta mengadakan pelatihan terhadap karyawan.

7. Marketing and Sales Director

Marketing and Sales Director adalah pejabat yang menentukan keberhasilan hotel dalam menjual produk hotel kepada konsumen.

8. Food \& Beverage Manager

F\&B Manager adalah pejabat yang bertugas mengelola Food and Beverage Department. Untuk dapat menyajikan makanan dan minuman berkualitas yang disenangi tamu. Merencanakan menu, memastikan bahwa setiap bawahanya dapat menyajikan makanan dengan cepat dan ramah, dan mengendalikan biaya Food and Beverage Department.

9. Security Director

Security Director bertanggung jawab atas keamanan hotel secara keseluruhan. Ruang lingkup pengamanan hotel meliputi para karyawan, para tamu, dan aset hotel. Security perlu menciptakan kondisi yang aman sehingga tamu betah tinggal di hotel dan para karyawan bekerja dengan nyaman.

\section{Analisis Regresi Linier Berganda}

Analisis regresi linear berganda berfungsi untuk mengetahui pengaruh variabel bebas (independent variable) yaitu Kepuasan ( ), dan Fasilitas, ( ), terhadap variabel terikat (dependent variable) yaitu Loyalitas Konsumen (Y). Analisis regresi linier berganda dalam penelitian ini menggunakan software SPSS for windows. Perhitungan persamaan regresi linear berganda adalah sebagai berikut :

$$
\mathrm{Y}=\mathrm{a}+\mathrm{b} 1 \mathrm{X} 1+\mathrm{b} 2 \mathrm{X} 2+\mathrm{b} 3 \mathrm{X} 3+\mathrm{e}
$$

Analisis regresi linear berganda dalam penelitian ini menggunakan program SPSS yang dapat dilihat pada tabel berikut ini:

Tabel 1

Hasil Regresi Linear Berganda Coefficientsa

\begin{tabular}{|c|c|c|c|c|c|}
\hline \multirow[t]{2}{*}{ Model } & \multicolumn{2}{|c|}{$\begin{array}{l}\text { Unstandardized } \\
\text { Coefficients }\end{array}$} & \multirow{2}{*}{\begin{tabular}{|c|} 
Standardized \\
Coefficients
\end{tabular}} & \multirow[b]{2}{*}{$\mathrm{t}$} & \multirow[b]{2}{*}{ Sig. } \\
\hline & B & \begin{tabular}{|l} 
Std. \\
Error
\end{tabular} & & & \\
\hline 1 (Constant) & 449 & 1.387 & & .324 & .748 \\
\hline Kepuasan & .136 & .063 & 216 & 2.170 & .035 \\
\hline Fasilitas & .587 & .087 & 669 & 6.714 & .000 \\
\hline
\end{tabular}

a. Dependent Variable: Loyalitas Konsumen

Dari Tabel 1 diketahui kolom

Unstandardized Coefficients pada bagian b diperoleh nilai b1 Kepuasan sebesar 0,136, nilai b2 Fasilitas sebesar 0,587 dan nilai konstanta (a) adalah 0,449 maka diperoleh persamaan regresi linier berganda sebagi berikut:

$\mathrm{Y}=0,449+0,136+0,587+\mathrm{e}$ 
Persamaan regresi linier berganda tersebut dapat diuraikan sebagai berikut:

a. Konstanta (a) $=0,449$, artinya jika variabel bebas yaitu Kepuasan, dan Fasilitas tetap, maka akan tetap ada 0,449 satuan Loyalitas Konsumen pada Hotel Platinum Rantauprapat Kabupaten Labuhanbatu .

b. Koefisien regresi X1 (b1) $=0,136$ artinya jika faktor Kepuasan meningkat sebesar satu satuan maka Loyalitas Konsumen pada Hotel Platinum Rantauprapat Kabupaten Labuhanbatu akan bertambah 0,136 satuan.

c. Koefisien regresi X2 (b2) $=0,587$, artinya jika variabel Fasilitas meningkat sebesar satu satuan maka Loyalitas Konsumen pada Hotel Platinum Rantauprapat Kabupaten Labuhanbatu akan bertambah 0,587 satuan.

\section{Koefisien Determinasi (R2)}

Koefisien determinasi menunjukkan besar kecilnya kontribusi pengaruh variabel bebas Kepuasan (X1), dan Fasilitas (X2), terhadap variabel terikat Loyalitas Konsumen (Y), dimana $0 \leq \leq 1$. Bila nilai semakin mendekati nilai 1 maka menunjukkan semakin kuatnya hubungan variabel bebas terhadap variabel terikat. Dan sebaliknya, jika determinan $\left(\mathrm{R}_{2}\right)$ semakin kecil atau mendekati nol, maka pengaruh pengaruh variabel bebas terhadap variabel terikat semakin lemah.

Hasil pengolahan dari analisis regresi linier berganda dapat dilihat pada tabel 2 berikut ini:
Tabel 2

Koefisien Determinasi (R2) Model Summaryb Model Summary ${ }^{\text {b }}$

\begin{tabular}{|c|c|c|c|c|}
\hline Model & $\mathrm{R}$ & R Square & $\begin{array}{l}\text { AdjustedR } \\
\text { Square }\end{array}$ & $\begin{array}{l}\text { Std. Error of the } \\
\text { Estimate }\end{array}$ \\
\hline 1 & $.802^{\mathrm{a}}$ & .643 & .628 & .88990 \\
\hline
\end{tabular}

a. Predictors: (Constant), Fasilitas, Kepuasan

b. Dependent Variable: Loyalitas Konsumen

Sumber: Hasil pengolahan Data

Primer (Kuesioner, 2016)

Berdasarkan Tabel 2 nilai $\mathrm{R}$ Square $=0,643$ berarti ada pengaruh kuat variabel Kepuasan dan Fasilitas terhadap Loyalitas Konsumen di Hotel Platinum Rantauprapat Kabupaten Labuhanbatu sebesar 64,3\%. Hal ini menunjukkan Loyalitas Konsumen dijelaskan oleh variabel Kepuasan, dan Fasilitas selebihnya sebesar $35,7 \%$ dijelasakan oleh variabel lain yang tidak termasuk dalam penelitian yang dilakukan.

\section{Pengujian Hipotesis Penelitian}

\section{Uji Parsial (Uji t)}

Uji parsial (uji t) dilakukan untuk menguji secara parsial apakah Kepuasan dan Fasilitas berpengaruh terhadap Loyalitas Konsumen di Hotel Platinum Rantauprapat Kabupaten Labuhanbatu, Untuk hasil uji parsial (uji t) dapat dilihat pada Tabel 3 berikut :

Tabel 3

$$
\begin{gathered}
\text { Hasil Uji Parsial (Uji t) } \\
\text { Coefficientsa }
\end{gathered}
$$

\begin{tabular}{|c|c|c|c|c|c|}
\hline \multirow[t]{2}{*}{ Model } & $\begin{array}{l}\text { Unst: } \\
\mathrm{d} \mathrm{Co}\end{array}$ & $\begin{array}{l}\text { andardize } \\
\text { efficients }\end{array}$ & \begin{tabular}{|l} 
Standardized \\
Coefficients
\end{tabular} & \multirow[b]{2}{*}{$\mathrm{t}$} & \multirow[b]{2}{*}{ Sig. } \\
\hline & B & $\begin{array}{l}\text { Std. } \\
\text { Error }\end{array}$ & Beta & & \\
\hline \multirow{3}{*}{$\begin{array}{ll}1 & \text { (Constan } \\
\text { t) } \\
\text { Kepuasa } \\
\text { n } \\
\text { Fasilitas }\end{array}$} & .449 & 1.387 & & .324 & .748 \\
\hline & .136 & .063 & .216 & 2.170 & .035 \\
\hline & .587 & .087 & .669 & 6.714 & .000 \\
\hline
\end{tabular}

\section{Coefficients $^{\mathrm{a}}$}

a. Dependent Variable: Loyalitas Konsumen 
Berdasarkan Tabel 4 terlihat bahwa nilai thitung untuk variabel Kepuasan sebesar 2,170 dan Fasilitas sebesar 6,174 dengan nilai signifikan untuk masing-masing variabel independen $(0,035)$; $(0,000)$. Sedangkan untuk nilai ttabel pada tabel statistik distribusi $\mathrm{t}$ dengan level of test $\alpha=5 \%$ dan df $1=(k-1)=2$ dan df $2=(n-k-1)=49$ sebesar 1,667 Berdasarkan kriteria bahwa jika nilai thitung> ttabel yakni $(2,170>$ 1,667); $(6,174>1,667)$ sehingga dapat disimpulkan bahwa variabel Kepuasan dan Fasilitas berpengaruh positif dan signifikan terhadap Loyalitas Konsumen.

\section{Uji Serempak (Uji F)}

Uji $F$ ini dilakukan untuk menguji secara serempak apakah Kepuasan dan Fasilitas berpengaruh terhadap Loyalitas Konsumen di Hotel Platinum Rantauprapat Kabupaten Labuhanbatu, dapat dilihat pada Tabel 5 berikut

Tabel 5

Hasil Uji Serempak (Uji F) ANOVAb

\begin{tabular}{|l|l|l|l|l|l|}
\hline Model & $\begin{array}{l}\text { Sumof } \\
\text { Squares }\end{array}$ & Df & $\begin{array}{l}\text { Mean } \\
\text { Square }\end{array}$ & F & Sig. \\
\hline 1 Regression & 69.888 & 2 & 34.944 & 44.126 & $.000^{\mathrm{a}}$ \\
Residual & 38.804 & 49 & .792 & & \\
Total & 108.692 & 51 & & & \\
\hline
\end{tabular}

a. Predictors: (Constant), Fasilitas, Kepuasan b. Dependent Variable: Loyalitas Konsumen Sumber: Hasil Pengolahan Data Primer (Kuesioner,2016)

\section{Berdasarkan Tabel}

menunjukkan bahwa hasil uji $\mathrm{F}$ sebesar 44,126 dengan tingkat signifikan sebesar 0.000 sedangkan nilai Ftabel pada tabel statistik distribusi $t$ dengan level of test $\alpha$ $=5 \%$ dan $\mathrm{df} 1=(\mathrm{k}-1)=2$ dan $\mathrm{df} 2=(\mathrm{n}-\mathrm{k}-$ 1) $=49$ sebesar 3,187. Jika dibandingkan nilai Fhitung $(44,126)>$ Ftabel $(3,187)$ maka disimpulkan bahwa secara serempak variabel Kepuasan dan Fasilitas berpangaruh positif dan signifikan terhadap Loyalitas Konsumen.

\section{Pembahasan Hasil Penelitian \\ Pengaruh Kepuasan Terhadap Loyalitas Konsumen}

Hasil deskriptif variabel Kepuasan Untuk item pertanyaan 3 (Hotel Platinum Rantauprapat Kabupaten Labuhanbatu memberikan kenyamanan kepada anda), artinya 32 orang responden $(61,5 \%)$ pengunjung Hotel Platinum Rantauprapat Kabupaten Labuhanbatu menjawab Sangat Setuju bahwa Hotel Platinum Rantauprapat Kabupaten Labuhanbatu memberikan kenyamanan.

Berdasarkan uji $\mathrm{t}$ variabel Kepuasan sebesar 2,170 dengan nilai signifikan untuk masing-masing variabel independen $(0,035)$. Sedangkan untuk nilai $\mathrm{t}_{\text {tabel }}$ pada tabel statistik distribusi $\mathrm{t}$ dengan level of test $\alpha=5 \%$ dan $\mathrm{df}_{1}=(\mathrm{k}-1)$ $=2$ dan $\mathrm{df}_{2}=(\mathrm{n}-\mathrm{k}-1)=49$ sebesar 1,667 Berdasarkan kriteria bahwa jika nilai $t_{\text {hitung }}>t_{\text {tabel }}$ yakni $(2,170>1,667)$, sehingga dapat disimpulkan bahwa variabel Kepuasan berpengaruh positif dan signifikan terhadap Loyalitas Konsumen.

Hal ini sejalan menurut Kotler dan Keller (2009) bahwa Kepuasan adalah tingkat perasaan seseorang setelah membandingkan kinerja (atau hasil) yang ia persepsikan dibandingkan dengan harapannya. Konsumen Hotel Platinum Rantauprapat Kabupaten Labuhanbatu memiliki komitmen untuk loyal berdasarkan fakta atau objektif, melihat objek secara realitas, mengamati, melihat segala sesuatu dengan akal dan persepsi yang nyata.

Variabel Kepuasan mempengaruhi Loyalitas Konsumen di Hotel Platinum Rantauprapat Kabupaten Labuhanbatu hal ini 
terjadi karena di Hotel Platinum Rantauprapat Kabupaten Labuhanbatu dapat memenuhi harapan konsumen serta dapat memuaskan konsumennya

\section{Pengaruh Fasilitas Terhadap Loyalitas Konsumen}

Hasil deskriptif variabel Fasilitas untuk item pertanyaan 3 (Fasilitas pendukung di Hotel Platinum Rantauprapat Kabupaten Labuhanbatu sudah memadai), 27 orang responden $(51,9 \%)$ menjawab Sangat Setuju. Ini artinya pengunjung Hotel Platinum Rantauprapat Kabupaten Labuhanbatu Sangat Setuju bahwa fasilitas pendukung di Hotel Platinum Rantauprapat Kabupaten Labuhanbatu sudah terpenuhi.

Berdasarkan uji t variabel Failitas $\left(\mathrm{X}_{2}\right)$, $\mathrm{t}_{\text {hitung }}(6,174)>\mathrm{t}_{\text {tabel }}(1,667)$ yang berarti Ho ditolak dan $\mathrm{Ha}$ diterima. Sedangkan nilai signifikan lebih kecil dari nilai probabilitas 0,05 atau nilai signifikan $0,000<0,05$. Dengan demikian dapat disimpulkan variabel Fasilitas $\left(\mathrm{X}_{2}\right)$ berpengaruh positif dan signifikan terhadap Loyalitas Konsumen Hotel Platinum Rantauprapat Kabupaten Labuhanbatu pada $\alpha=5 \%$

Hal ini sejalan dengan yang dikemukakan oleh Tjiptono (2008) mengemukakan fasilitas adalah sumber daya fisik yang harus ada sebelum suatu jasa ditawarkan kepada konsumen. Pada dasarnya fasilitas merupakan faktor yang menentukan untuk menginap disuatu hotel tertentu. Hal ini juga didukung oleh penelitian sebelumnya, Budianto (2014) dengan judul "Pengaruh Kualitas Pelayanan Dan Fasilitas terhadap Kepuasan Pelanggan di Hotel Narita Surabaya". Variabel yang diamati dalam penelitian tersebut adalah Kualitas Pelayanan $\left(\mathrm{X}_{1}\right)$, Fasilitas $\left(\mathrm{X}_{2}\right)$, dan Kepuasan Pelanggan (Y), Secara simultan menunjukkan nilai signifikansi $F_{\text {hitung }} 0,00$ lebih kecil daripada 0,05.

\section{Pengaruh Kepuasan dan Fasilitas terhadap Loyalitas Konsumen}

Berdasarkan hasil uji $\mathrm{F}$ bahwa nilai $F_{\text {hitung }}$ sebesar 44,126 dengan tingkat signifikan sebesar 0.000 dan nilai $F_{\text {tabel }}$ pada tabel statistik distribusi $\mathrm{t}$ dengan level of test $\alpha=5 \%$ dan $\mathrm{df}_{1}=(\mathrm{k}-1)=2$ dan $\mathrm{df}_{2}=(\mathrm{n}-\mathrm{k}-1)=49$ sebesar 3,187. Jika dibandingkan nilai $F_{\text {hitung }}(44,126)>F_{\text {tabel }}$ $(3,187)$ maka disimpulkan bahwa secara serempak variabel Kepuasan dan Fasilitas berpangaruh positif dan signifikan terhadap Loyalitas Konsumen

Hal ini sejalan dengan Griffin (2007) mengemukakan konsep loyalitas mengarah kepada prilaku (behaviour) dibandingkan dengan sikap (attitude) dan seorang pelanggan yang loyal akan memperlihatkan prilaku pembelian yang didefinisikan sebagai pembeli yang teratur dan diperlihatkan sepanjang waktu oleh beberapa unit pembuatan keputusan". Konsumen yang loyal merupakan aset bagi perusahaan, dan untuk mengetahui pelanggan yang loyal perusahaan harus mampu memenuhi harapan pelanggan serta dapat memuaskan pelanggannya

Hal ini juga didukung oleh penelitian yang dilakukan Japarianto (2014) dengan judul "Pengaruh Kepuasan, Hambatan berpindah dan Penyediaan Fasilitas terhadap Loyalitas Konsumen di Hotel Novotel Surabaya". Variabel yang diamati dalam penelitian ini adalah Kepuasan $\left(\mathrm{X}_{1}\right)$, Hambatan berpindah $\left(\mathrm{X}_{2}\right)$, Penyediaan Fasilitas $\left(\mathrm{X}_{3}\right)$ dan Loyalitas Konsumen (Y). Hasil penelitian menunjukkan Kepuasan, hambatan berpindah, dan penyediaan fasilitas secara simultan berpengaruh terhadap Loyalitas pelanggan Hotel Novotel di Surabaya.

\section{Kesimpulan}


Kesimpulan yang dirumuskan penulis dalam penelitian dengan judul "Pengaruh Kepuasan dan Fasilitas Terhadap Loyalitas Konsumen di Hotel Platinum Rantauprapat Kabupaten Labuhanbatu" adalah:

a. Secara parsial Kepuasan berpengaruh positif dan signifikan terhadap Loyalitas Konsumen di Hotel Platinum Rantauprapat Kabupaten Labuhanbatu.

b. Secara parsial Fasilitas berpengaruh positif dan signifikan terhadap Loyalitas Konsumen di Hotel Platinum Rantauprapat Kabupaten Labuhanbatu

c. Secara serempak Kepuasan dan Fasilitas berpengaruh positif dan signifikan terhadap Loyalitas Konsumen di Hotel Platinum Rantauprapat Kabupaten Labuhanbatu.

\section{Daftar Pustaka}

Aritonang, Lerbin R. 2007. Riset Pemasaran. Jakarta: Ghalia Indonesia Berman, Barry, and Joel R. Evans, 2007, Retail Management, New Jersey: Prentice Hall.

Buchari Alma.2007,Manajemen Pemasaran \& Pemasaran Jasa. Bandung: Alfabeta.

Dimyati dan Mudjiono. 2007. Belajar dan Pembelajaran. Jakarta: Rineka Cipta

Griffin, Ricki W dan Ronal J Ebert. 2007, Bisnis Edisi 8. Jakarta: Erlangga

Husein Umar. 2007, Metode Penelitian Untuk Skripsi Dan Tesis Bisnis, Jakarta : Raja Grafindo Persada Moekijat 2008. Manajemen Personalia dan Sumber Daya Manusia.Yogyakarta:BFFE
Nitisemito S. Alek, 2008, Manajemen Personalia, Edisi kedua, Ghalia Indonesia.

Kotler, Philip, Keller Kevin Lane. 2007. Manajemen Pemasaran. Edisi Keduabelas. Jakarta: Indeks.

Kotler, Philip dan Keller, Kevin Lane, 2009. Manajemen Pemasaran, Edisi Ketiga Belas, Jilid Satu, Erlangga, Jakarta.

Oliver, Sandra. 2007. "Strategi Public Relations". Penerbit Erlangga. Jakarta

Sunarto. 2006. Pengantar Manajemen Pemasaran. Cet. 1. Yogyakarta:Ust Press.

Sulastiyono Agus. 2006. Manajemen Penyelenggaraan Hotel. Bandung: Alfabeta.

Situmorang dan Lufti, 2014. Analisis Data untuk Riset Manajemen dan Bisnis, USU Press, Medan.

Suhardi. 2008. Perancangan Sistem Kerja Dan Ergonomi Industri. Prosiding. Seminar Nasional ergonomic

Supramono dan Jony Oktavian Haryanto 2006. Desain Proposal Penelitian Studi Pemasaran, Andi, Yogyakarta.

Sugiyono, 2011. Metode Penelitian Kuantitatif kualitatif dan R\&D, Alfabeta, Bandung.

Tjiptono, Fandy, 2008. Strategi Pemasaran, Penerbit Andi, Yogyakarta.

Tjiptono,Fandy, 2011. Manajemen dan Strategi Merek, Penerbit Andi, Yogyakarta.

Tjiptono, Fandy. 2012. Service Management "Mewujudkan Layanan Prima". Yogyakarta, Penerbit Andi, Yogyakarta

Zeithaml, Bitner and Gremler, 2006, Service Marketing, Fourth edition, 
Prentice Hall; Exclusive right by Mc Graw-Hill.

Japarianto Edwin dan S. Chen Yenni, 2014. "Pengaruh Kepuasan, Hambatan Berpindah dan Penyediaaan Fasilitas terhadap

Loyalitas Konsumen Di Hotel Novotel Surabaya", Jurnal Strategi Pemasaran Volume 2 No.1.

Yunus dan Budiant, 2014. "Pengaruh

Kualitas Pelayanan dan Fasilitas Terhadap Kepuasan Pelanggan", Jurnal Ilmu dan Riset Manajemen Vol 3 No.12 Sekolah Tinggi Ilmu Ekonomi Indonesia (STIESIA), Surabaya

Hapsari Mengayu Respati, 2011. "Pengaruh Kualitas Pelayanan, Fasilitas Fisik dan Promosi Terhadap Kepuasan Konsumen Pada Hotel Semesta Semarang, Skripsi Fakultas Ekonomi Universitas Negeri Semarang. 